\title{
THE ROLE OF TECHNOLOGY SAVVINESS IN MUSLIM ONLINE SHOPPING (MOS)
}

\author{
Jhanghiz Syahrivar ${ }^{1,3}$, Frangky Selamat ${ }^{2}$, Chairy Chairy ${ }^{3}$ \\ ${ }^{1}$ Department of Marketing, Corvinus University of Budapest, Hungary \\ Email:jhanghiz@president.ac.id \\ ${ }^{2}$ Department of Management, Universitas Tarumanagara, Indonesia \\ Email:frangkys@fe.untar.ac.id \\ ${ }^{3}$ School of Business, President University, Indonesia \\ Email: chairy@president.ac.id
}

Masuk : 16-05-yyyy, revisi: 20-05-2020, diterima untuk diterbitkan : 20-05-2020

\begin{abstract}
ABSTRAK
Kemajuan e-commerce dalam satu dekade terakhir telah mengubah cara konsumen Muslim memilih dan membeli produk yang dapat memenuhi gaya hidup mereka. Sejak itu, banyak toko online bermunculan di Indonesia yang menyasar pangsa pasar Muslim yang besar namun terbagi-bagi. Banyak penelitian tentang belanja online berfokus pada fitur toko online untuk menarik calon pelanggan; namun, sepengetahuan kami, belum ada penelitian yang mengaitkan perilaku belanja melalui toko online Muslim (MOS) dengan penguasaan dan pengetahuan terkait teknologi digital. Penelitian ini melibatkan 202 responden Muslim Indonesia yang secara reguler membeli produk Islami melalui platform MOS. Hipotesis diuji menggunakan Structural Equation Modeling (SEM) melalui perangkat lunak AMOS. Temuan menunjukkan bahwa penguasaan teknologi secara positif dan signifikan mempengaruhi persepsi keramahan situs web dan bahwasanya Muslim yang cerdas secara teknologi memiliki kecendrungan lebih tinggi untuk berbelanja melalui platform MOS. Kontribusi teoretis maupun implikasi manajerial juga turut dibahas dalam penelitian ini.
\end{abstract}

Kata Kunci: Belanja Online Muslim, Penguasaan Teknologi Digital, Keramahan Situs Web

\section{ABSTRACT}

The advancement of e-commerce in the last decade has transformed the way Muslim consumers select and purchase products that meet their lifestyles. Ever since, many online shops have emerged in Indonesia targeting Muslim market which is huge but fragmented. Many studies on online shopping have focused on the features of online shops to attract potential customers; however, to our best knowledge, none has linked Muslim Online Shopping (MOS) behaviour with Muslims' mastery and knowledge of digital technology or called technology-savviness. This study involved 202 Indonesian Muslim respondents who regularly bought Islamic products via MOS platforms. The hypotheses were tested using Structural Equation Modelling (SEM) via AMOS software. The findings suggest that technology savviness positively and significantly influences perceived website friendliness and that Muslims who are technology savvy are more inclined towards MOS. Theoretical contributions as well as managerial implications are discussed in this study.

Keywords: Muslim Online Shopping, Technology Savviness, Website Friendliness

\section{INTRODUCTION}

Indonesia is home to more than 200 million Muslims or roughly 13 percent of total Muslim population in the world (Mashuri \& Zaduqisti, 2019). As of 2010, the country was ranked number one in the world in terms of Muslim population (PewResearch, 2015). In the recent years, the country has witnessed a surge in demand of halal products (Setiawati, Chairy, \& Syahrivar, 2019). Moreover, Indonesian Muslims are the highest spenders on Halal products, followed by Turkey, Pakistan Egypt, Bangladesh, Iran and Saudi Arabia (Khidhir, 2018).

The advancement of technology in e-commerce in the last decade has transformed the way Muslim consumers select and purchase products that meet their lifestyles. Ever since, many online shops ran by Muslim and non-Muslims alike have pop up in Indonesia targeting Muslim market which is huge but fragmented. Fragmented in a sense that Indonesian Muslims differ in terms of religious commitments and needs. Some popular Muslim Online Shop (MOS) platforms in Indonesia are 
Zoya, Hijabenka, Zalora, Muslimmarket, etc. All in all, the changing of demographic as well as increasing purchasing power of Muslim consumers around the world have made Islamic marketing and consumption an important research field (Sandıkçı, 2011).

Previous studies on online shopping have focused on the features of online shops to attract customers (Belanche, Casaló, \& Guinalíu, 2012; Rezaei, Amin, \& Ismail, 2014; Qi, Law, \& Buhalis, 2017); however, to our best knowledge, no research thus far has linked Muslim Online Shopping (MOS) behavior with Muslims' overall knowledge and ability to utilize digital technology. This study aims to investigate the role of technology savviness and website friendliness in online shopping behavior among Muslims.

Digital technology, such as cellular phones and laptops, coupled with e-commerce have made shopping one click away. While millennials are able to utilize new digital technology like the back of their hands, older generations might struggle to learn and keep up. For those who run their businesses online, having potential customers struggle with their gadgets, internet and company websites can certainly pose some challenges. Previous studies indicate that technology savviness and website friendliness play roles in online purchase intention (Lean et al., 2009; Belanche et al., 2012; Qi et al., 2017).

In 2019 there are more than 4 billion internet users in the world (Morcos et al., 2019) of which 190 million of them (roughly five percent) came from countries in South East Asia, such as Indonesia (Yuana et al., 2019). Majority of internet users in Indonesia are millennials (born between 19802000) of which, in terms of gender, male and female are equally active (Setyastuti et al., 2019). It was reported that 18 million internet users in Indonesia engage in online shopping activities (Hidayatno, Destyanto, \& Fadhil, 2019). Although the figure seems lucrative, it also means that the majority of Indonesians are still unfamiliar with online shopping. It is a big issue since the lack of technology literacy or mastery may discourage online shopping activities and technology consumption in general (Kurt et al., 2014; Ekpo et al., 2018).

The rest of this paper is organized as follows: first is the literature review where the core theories are explored. Second is the research methodology where the research steps taken to obtain and analyze the data are elaborated. Third is the results where the statistical findings are presented. Fourth is the conclusion where the summary of this study, the theoretical contributions as well as the managerial implications are given.

\section{LITERATURE REVIEW}

Consumption cannot be separated from culture and religious beliefs (Chairy \& Syahrivar, 2019). Devoted Muslims would purchase products and services that conform to Sharia law. Sharia law governs which products or services are Halal (permissible) and Haram (forbidden) to consume. Moreover, products that meet the Sharia law or Halal requirements instill a feeling of safety and security among Muslim consumers (Demirci, Soon, \& Wallace, 2016; Syahrivar, \& Azizah, 2018; Zainudin, Hasan, \& Othman, 2019). In Indonesia, Halal certification and control is managed by the Halal Products Certification Agency (BPJPH) which was established in 2017. The agency is under the Indonesian Ministry of Religious Affairs (http://halal.go.id/). Previously, it was managed by Indonesian Ulema Council (MUI).

In order to appeal to Muslim consumers and distinguish themselves from competitors, stores may implement Islamic branding strategy. According to Wilson and Liu (2011), Islamic branding strategy incorporates several elements, such as 'Halal' logo, brand names that are inspired by Islam 
or are familiar to Muslims, Arabic calligraphy and other Islamic symbolism. Muslim Online Shop (MOS) typically uses these elements in their website in order to attract Muslim consumers.

In this study, Muslim Online Shopping (MOS) is defined as shopping activities of Islamic goods through online platforms. Online shopping involves an exchange between buyers and sellers (vendors) through virtual mediums of which trust is the key (Rezaei et al., 2014). Meanwhile, Islamic goods are defined as products marketed to Muslim consumers primarily for the observance of Sharia or Islamic laws. Islamic goods include a wide range of categories, such as: clothing, holiday resorts, cosmetic, decorative objects, music, etc. (Sandıkç1, 2011; Syahrivar \& Pratiwi, 2018). Devout Muslims are obliged to purchase only that which is 'Halal' or permissible by God. Islamic or Halal goods are not only pertaining to the materials being used to create the goods but also the process and transaction involved.

Technology savviness is defined as the ability to utilize multiple digital technologies and maximize their features (Lavieri, Dai, \& Bhat, 2018). Tech-savvy customers engage with companies through multiple social media platforms. For instance, they are also able to cross-check product information from several online sources and thus are more knowledgeable about the latest trend (Kumar et al., 2016). Moreover, not only are they familiar with multiple online platforms, techsavvy customers are also sought after by others for advice on new digital technology (Parasuraman, 2000; Kumar et al., 2016).

Website friendliness is defined as the simplicity in navigating an online platform so that users are able to obtain what they look for within the platform effectively and efficiently (Belanche et al., 2012). Several notable features of a so called friendly website includes credible and up to date information, website speed and easy and fast transaction (Belanche et al., 2012; Qi et al., 2017). In the digital era, website friendliness plays a pivotal role in business; potential consumers may come to learn about a company through online sources, such as their official website and social media platforms. What they see online will influence their perceptions about the company. Moreover, for ease-of-use, website contents should be adapted in accordance with digital devices (e.g. laptop, mobile phones) used by their customers.

The relationship between consumers' mastery in digital technology and their perceptions on website friendliness is not obvious. A study by Zhong et al. (2014) involved technology-savvy undergraduate students as evaluators of website performance in the context of China. The results of their study imply that tech-savvy users assessed the website performance in terms of accessibility (e.g. download speed), usability (e.g. registration process), and functionality (e.g. accurate information) favorably. Meanwhile, a study by Revadi et al. (2018) college students and faculty members implies that low technology skill mastery could erode users' experience in accessing and navigating a website. We argue that Muslims who are considered technology-savvy are able to navigate a new website with ease or less difficulty hence making the website seems more user-friendly to them compared to those who are less technology-savvy. Due to their lack of technology literacy, the latter category is prone to confusion or frustration upon encountering a new website which negatively affects the perceived website friendliness. Therefore, the hypothesis is formulated as follows:

$\mathrm{H}_{1}$ : Technology savviness has a positive influence towards website friendliness.

Previous studies suggest that technology savviness plays a role in the adoption of new online platforms and new technology in general (Sieber \& Sabatier, 2003; Lean et al., 2009; Lavieri et al., 2017). Consumers with low technology literacy will struggle to fully maximize the features of 
their technology devices as well as to navigate online platforms (Revadi et al., 2018). Their lack of technology skills makes them less confident and less inclined towards purchasing products via online platforms. Alternatively, users who are technology-savvy are more confident and more willing to purchase products online. Therefore, the hypothesis is formulated as follows:

$\mathrm{H}_{2}$ : Technology savviness has a positive influence towards Muslim Online Shopping (MOS).

Previous studies suggest that website friendliness affects satisfaction with online platforms and the intentions to use them (Lean et al., 2009; Belanche et al., 2012; Qi et al., 2017). Internet users may leave a poorly designed website, especially when they experience difficulties finding what they need (Tan \& Wei, 2006). We argue that Muslims who are technology-savvy are more inclined towards MOS because of enhanced perceptions on website friendliness. Therefore, the hypothesis is formulated as follows:

$\mathrm{H}_{3}$ : Website friendliness mediates the relationship between technology savviness and MOS.

\section{RESEARCH METHODOLOGY}

The theoretical framework in this study is presented in Figure 1. Technology Savviness (TCS) is an exogenous variable, Website Friendliness (WBF) is the mediating variable and Muslim Online Shopping (MOS) is the endogenous variable.

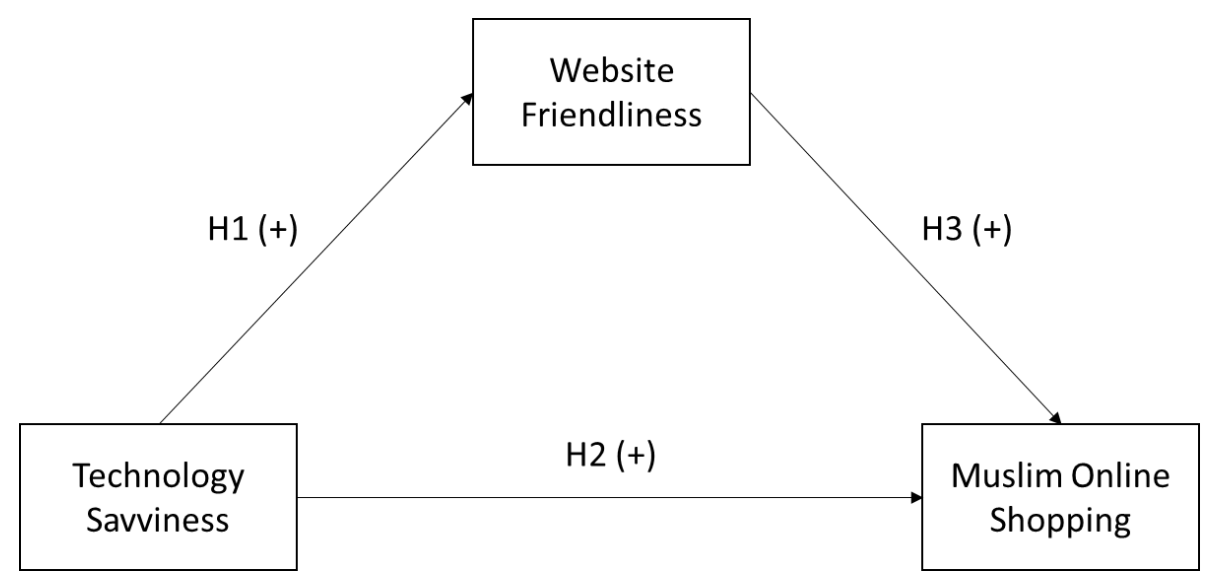

Figure 1. Theoretical Framework

The population of this study was Muslim consumers who regularly purchased Islamic products (e.g. clothes, foods accessories, etc.) through Muslim Online Shops (MOS). For this reason, we employed purposive sampling. We distributed online questionnaires to Muslim respondents via several Muslim sites and social media dealing Islamic products. To be considered in this study, respondents had to declare which MOS they regularly visited and made online purchases. We also gauged the frequency of purchases of our Muslim respondents via MOS to further determine if they were the right respondents for this study. Those who indicated that they never purchased Islamic products via MOS were eliminated from this study. Out of 254 respondents, only 202 respondents were deemed valid for satisfying the criteria that we set and having no missing responses. The summary of the respondent profile is presented in Table 1.

Table 1. Respondent Profile

\begin{tabular}{llll}
\hline & & Frequency & $\%$ \\
\hline Gender & Male & 98 & $48.51 \%$ \\
\hline & Female & 104 & $51.49 \%$ \\
\hline
\end{tabular}




\begin{tabular}{llll}
\hline Age & $18-29$ & 108 & $53.47 \%$ \\
\hline & $30-39$ & 87 & $43.07 \%$ \\
\hline Education & $40-49$ & 5 & $2.48 \%$ \\
\hline & $>50$ & 2 & $0.99 \%$ \\
\hline & Primary Education & 13 & $6.44 \%$ \\
\hline Status & Secondary Education & 34 & $16.83 \%$ \\
\hline & Higher Education & 155 & $76.73 \%$ \\
\hline & Single & 116 & $57.43 \%$ \\
\hline Total & Married & 85 & $42.08 \%$ \\
\hline
\end{tabular}

The measurement scale for Technology Savviness (TES) was adapted from Parasuraman (2000), the measurement scale for Website Friendliness (WEF) was adapted from Qi et al. (2017), and the measurement scale for Muslim Online Shopping (MOS) was adapted from Overby and Lee (2006). A pre-test of 30 respondents was conducted to assess the reliabilities of the measurement scales. Table 2 presents the operationalization of each variable, its measure and reliability.

Table 2. The Operationalization of Variables

\begin{tabular}{|c|c|c|c|}
\hline Variables & Indicators & Reliability & Measurement \\
\hline $\begin{array}{l}\text { Technology } \\
\text { Savviness } \\
\text { (TCS) }\end{array}$ & $\begin{array}{l}\text { 1. Being sought after by people for } \\
\text { advice on new digital technology. } \\
\text { 2. Being one of the first to use new } \\
\text { digital technology when it appears. } \\
\text { 3. Being able to use multiple digital } \\
\text { technology with ease. }\end{array}$ & 0.763 & \multirow{3}{*}{$\begin{array}{l}\text { Likert Scale } \\
1-5 \\
1=\text { Strongly } \\
\text { Disagree, } 5= \\
\text { Strongly Agree }\end{array}$} \\
\hline $\begin{array}{l}\text { Website } \\
\text { Friendliness } \\
\text { (WBF) }\end{array}$ & $\begin{array}{l}\text { 1. Website information is credible } \\
\text { 2. Website download/response speed } \\
\text { is relatively fast. } \\
\text { 3. Payment function is easy and } \\
\text { simple to use. }\end{array}$ & 0.873 & \\
\hline $\begin{array}{l}\text { Muslim Online } \\
\text { Shopping } \\
\text { (MOS) }\end{array}$ & $\begin{array}{l}\text { 1. Muslim Online Shop (MoS) as the } \\
\text { first preference. } \\
\text { 2. Preference for Muslim Online } \\
\text { Shop (MoS) over traditional } \\
\text { retailers. } \\
\text { 3. Muslim Online Shop (MoS) as the } \\
\text { primary source of purchase. }\end{array}$ & 0.858 & \\
\hline
\end{tabular}

First, we conducted Exploratory Factor Analysis (EFA) via SPSS software in order to see if each item belongs to the construct it intends to measure. Secondly, we tested our hypotheses and the fitness of our model using Structural Equation Modelling (SEM) via AMOS software. A guideline by Schreiber (2017) was used in this study. 


\section{RESULTS AND DISCUSSION}

The descriptive analysis is presented in Table 3. The Mean of each item is relatively high which indicates the tendency towards agreement (agree/strongly agree). Meanwhile the Standard Deviation (S.D) of each item is less than 1 which indicates that the value of the case is spread close to the Mean value.

Table 3. Descriptive Statistics

\begin{tabular}{lccccc}
\hline & N & Min & Max & Mean & S.D. \\
\hline TCS1 & 202 & 1 & 5 & 4.01 & .829 \\
\hline TCS2 & 202 & 1 & 5 & 3.87 & .806 \\
\hline TCS3 & 202 & 1 & 5 & 4.08 & .790 \\
\hline WBF1 & 202 & 1 & 5 & 3.64 & .748 \\
\hline WBF2 & 202 & 1 & 5 & 3.78 & .748 \\
\hline WBF3 & 202 & 1 & 5 & 3.69 & .802 \\
\hline MOS1 & 202 & 1 & 5 & 3.99 & .852 \\
\hline MOS2 & 202 & 1 & 5 & 3.88 & .864 \\
\hline MOS3 & 202 & 1 & 5 & 4.01 & .875 \\
\hline
\end{tabular}

Based on Table 4, the value of KMO (Kaiser-Meyer-Olkin Measure) is 0.823 (>0.5) which indicates that the samples are sufficient for Exploratory Factor Analysis or EFA (Kaiser, 1974).

Table 4. Kaiser-Meyer-Olkin Measure

\begin{tabular}{lrr}
\hline \multicolumn{2}{c}{ KMO and Bartlett's Test } & .823 \\
\hline Kaiser-Meyer-Olkin Measure of Sampling Adequacy. & 856.052 \\
\hline Bartlett's Test of Sphericity & Approx. Chi-Square & 36 \\
\cline { 2 - 3 } & $\mathrm{df}$ & .000 \\
\cline { 2 - 3 }
\end{tabular}

The result of factor analysis (Rotated Component Matrix) using Varimax method is presented in Table 5. The factor loading of each item exceeds 0.7 and each item falls into the factor or construct it is supposed to measure.

Table 5. Factor Loadings

\begin{tabular}{|c|c|c|c|}
\hline \multicolumn{4}{|c|}{ Rotated Component Matrix ${ }^{a}$} \\
\hline & \multicolumn{3}{|c|}{ Component } \\
\hline & 1 & 2 & 3 \\
\hline TCS1 & & & .804 \\
\hline TCS2 & & & .816 \\
\hline TCS3 & & & .783 \\
\hline WBF1 & .834 & & \\
\hline WBF2 & .844 & & \\
\hline WBF3 & .887 & & \\
\hline MOS1 & & .790 & \\
\hline MOS2 & & .868 & \\
\hline MOS3 & & .867 & \\
\hline
\end{tabular}

The adequacy of three factors was evaluated with two criteria: the cumulative percentage of variance explained by the three factors should exceed $60 \%$ and the corresponding eigenvalues should be greater than 1 (Nunayon, Olanipekun, \& Famakin, 2020). Based on Table 6, the total 
eigenvalues are $2.191(>1)$ and the cumulative percentage of variance explained is $76.506 \%$ $(>50 \%)$.

Table 6. Total Variance Explained

\begin{tabular}{lrrrrrrrrr}
\hline $\begin{array}{l}\text { Compo } \\
\text { nent }\end{array}$ & \multicolumn{3}{c}{ Initial Eigenvalues } & \multicolumn{3}{c}{$\begin{array}{c}\text { Extraction Sums of } \\
\text { Squared Loadings }\end{array}$} & \multicolumn{3}{c}{$\begin{array}{c}\text { Rotation Sums of } \\
\text { Squared Loadings }\end{array}$} \\
\cline { 2 - 11 } & $\begin{array}{c}\text { Tot } \\
\text { al }\end{array}$ & $\begin{array}{c}\text { \% of } \\
\text { Varia } \\
\text { nce }\end{array}$ & $\begin{array}{c}\text { Cumula } \\
\text { tive } \%\end{array}$ & $\begin{array}{c}\text { Tot } \\
\text { al }\end{array}$ & $\begin{array}{c}\text { \% of } \\
\text { Varia } \\
\text { nce }\end{array}$ & $\begin{array}{c}\text { Cumula } \\
\text { tive } \%\end{array}$ & $\begin{array}{c}\text { Tot } \\
\text { al }\end{array}$ & $\begin{array}{c}\text { \% of } \\
\text { Varia } \\
\text { nce }\end{array}$ & $\begin{array}{c}\text { Cumula } \\
\text { tive \% }\end{array}$ \\
\hline 1 & 4.0 & 45.45 & 45.454 & 4.0 & 45.45 & 45.454 & 2.3 & 26.14 & 26.147 \\
& 91 & 4 & & 91 & 4 & & 53 & 7 & \\
\hline 2 & 1.6 & 18.75 & 64.208 & 1.6 & 18.75 & 64.208 & 2.3 & 26.01 & 52.158 \\
& 88 & 4 & & 88 & 4 & & 41 & 2 & \\
\hline 3 & 1.1 & 12.29 & 76.506 & 1.1 & 12.29 & 76.506 & 2.1 & 24.34 & 76.506 \\
& 07 & 8 & & 07 & 8 & & 91 & 8 & \\
\hline
\end{tabular}

Extraction Method: Principal Component Analysis.

After that we performed Confirmatory Factor Analysis (CFA) using AMOS software. The final SEM model with standardized estimates are presented in Figure 2. The standardized regression weight between Technology Savviness (TCS) and Website Friendliness (WBF) is 0.453 , meaning when TCS goes up by 1 standard deviation, WBF goes up by 0.452 standard deviations; the standardized regression weight between TCS and Muslim Online Shopping (MOS) is 0.589, meaning when TCS goes up by 1 standard deviation, MOS goes up by 0.589 standard deviations; the standardized regression weight between WBF and MOS is 0.11 , meaning when WBF goes up by 1 standard deviation, MOS goes up by 0.11 standard deviations.

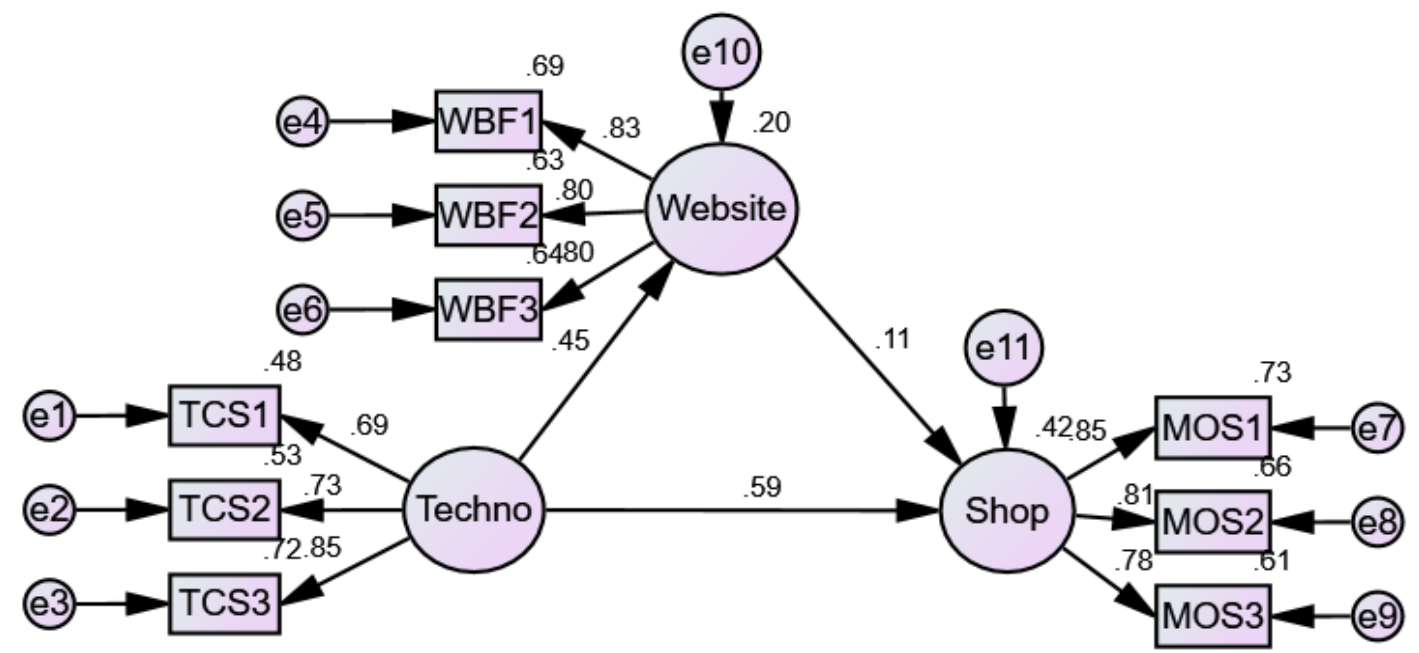

Figure 2. SEM Model

From the results of Squared Multiple Correlations, it is estimated that TCS can explain the variance in WBF by 20.4 percent. Moreover, it is also estimated that TCS and WBF can explain 41.7 percent of the variance in MOS. We incline to say that the abilities of the predictors in explaining MOS are relatively high.

Indicators of model fit and their threshold (Schreiber, 2017) are presented in Table 7. We are inclined to say that our SEM model has a good fit. 
Table 7. Goodness of Fit

\begin{tabular}{llll}
\hline Fit Index & Recommended Thresholds & Results & Notes \\
\hline RMSEA & $<0.08$ & 0.065 & Good Fit \\
\hline SRMR & $<0.08$ & 0.0478 & Good Fit \\
\hline GFI & $>0.95$ & 0.956 & Good Fit \\
\hline NFI & $>0.95$ & 0.949 & Moderate Fit \\
\hline TLI & $>0.95$ & 0.964 & Good Fit \\
\hline CFI & $>0.95$ & 0.976 & Good Fit \\
\hline
\end{tabular}

Another criterion to evaluate the fitness of a structural equation model is the Average Variance Explained or AVE. Each variable's AVE should be higher than 0.5 (Henseler, Hubona, \& Ray, 2016). The AVE of Technology Savviness (TES), Website Friendliness (WEF) and Muslim Online Shopping (MOS) are $0.642,0.732$ and 0.709 consecutively hence satisfying the all the necessary requirements.

The regression results are presented in Table 8 . We found that technology savviness influence website friendliness positively and significantly [H1 is accepted; $\mathrm{p}<0.05]$. Technology savviness also influences Muslim Online Shopping (MOS) positively and significantly $\left[\mathrm{H}_{2}\right.$ is accepted; $\mathrm{p}<0.05]$. Meanwhile, the mediation role of website friendliness in the relationship between technology savviness and MOS cannot be supported in this study $\left[\mathrm{H}_{3}\right.$ is rejected; $\left.\mathrm{p}>0.05\right]$.

Table 8. Effects

\begin{tabular}{lllrrrrl}
\hline & & Estimate & S.E. & C.R. & P & Note \\
\hline Website & $<---$ & Techno & .487 & .095 & 5.131 & $* * *$ & H1 is supported \\
\hline Shop & $<---$ & Techno & .744 & .122 & 6.084 & $* * *$ & H2 is supported \\
\hline Shop & $<---$ & Website & .129 & .096 & 1.346 & .178 & H3 is rejected \\
\hline
\end{tabular}

\section{SUMMARY AND RECOMMENDATION}

In this study, we manage to prove that technology savviness improves perceived website friendliness. Muslims who are technology-savvy are also tend to perceive Muslim Online Shop (MOS) platforms as more user-friendly. This study provides empirical support on what was previously hinted in previous studies, such as Zhong et al. (2014) and Revadi et al. (2018).

We also manage to prove that technology savviness is pivotal to determining Muslims' preferences towards MOS platforms. It means that the preference towards MOS platforms is higher among Muslim respondents with higher digital technology literacy. This study provides empirical supports to previous studies (Sieber \& Sabatier, 2003; Lean et al., 2009; Lavieri et al., 2017)

Unfortunately, this study cannot support the mediation role of website friendliness in relationship between technology savviness and MOS. We argue that this result occurs because our Muslim respondents are dealing with multiple MOS platforms as they had indicated in the questionnaire. As a result, the experience may vary across platforms. This merit further investigation in the future and a case study on each MOS platform in order to generate a more accurate picture.

To our best knowledge, this is the first attempt to assess the relationship between technology savviness of Muslim consumers and their preferences towards Muslim Online Shop (MOS). Therefore, the result of this study is expected to close the gap in the Islamic consumption literature. Secondly, the relationship between technology savviness and website friendliness was hinted but less explored in the previous studies. Therefore, the results of our study are expected to provide empirical evidence that such a relationship exists. Future studies should examine the relationship 
between the two variables with more rigorous measurements in order to add weight to the results of this study.

Our study has some limitations. The measurement scales used in this study, such as website friendliness scale, were relatively brief hence they might not be able to capture the whole aspects of the constructs under investigation. The reliability tests, however, suggest that the Cronbach's Alpha of each variable is modest to high. Secondly, as we have pointed out earlier, this study investigates MOS in general which may influence our respondents' overall attitudes, especially those who engage with multiple MOS platforms. Future studies should investigate specific MOS platforms in order to generate more accurate findings.

Based on the current findings, we thus advise that Muslim entrepreneurs can pay attention on technology know-how of their potential customers and design programs that enable their potential customers to get familiarized with their online platforms. By improving the technology literacy of their customers, Muslim Online Shops may improve customers' perceived website friendliness as well as their intentions to purchase Islamic products through their platforms.

\section{REFERENCES}

Badan Penyelenggara Jaminan Produk Halal (BPPJH). Retrieved on 14 May 2020 from http://halal.go.id/.

Belanche, D., Casaló, L. V., \& Guinalíu, M. (2012). Website usability, consumer satisfaction and the intention to use a website: The moderating effect of perceived risk. Journal of Retailing and Consumer Services, 19(1), 124-132.

Chairy, \& Syahrivar, J. (2019). Bika Ambon of Indonesia: history, culture, and its contribution to tourism sector. Journal of Ethnic Foods, 6(2), 1-6.

Demirci, M. N., Soon, J. M., \& Wallace, C. A. (2016). Positioning food safety in Halal assurance. Food Control, 70, 257-270.

Ekpo, A. E., DeBerry-Spence, B., Henderson, G. R., \& Cherian, J. (2018). Narratives of technology consumption in the face of marketplace discrimination. Marketing Letters, 29(4), 451-463.

Henseler, J., Hubona, G., \& Ray, P. A. (2016). Using PLS path modeling in new technology research: updated guidelines. Industrial Management and Data Systems, 116(1), 2-20

Hidayatno, A., Destyanto, A. R., \& Fadhil, M. (2019). Model Conceptualization on E-Commerce Growth Impact to Emissions Generated from Urban Logistics Transportation: A Case Study of Jakarta. Energy Procedia, 156, 144-148.

Kaiser, H. F. (1974). An index of factorial simplicity. Psychometrika, 39(1), 31-36.

Khidhir, S. (2018). Halal Indonesia: A booming industry. Theaseanpost.com. Retrieved on 14 May 2020 from: https://theaseanpost.com/article/halal-indonesia-booming-industry

Kumar, A., Bezawada, R., Rishika, R., Janakiraman, R., \& Kannan, P. K. (2016). From social to sale: The effects of firm-generated content in social media on customer behavior. Journal of Marketing, 80(1), 7-25.

Kurt, N., Savaş, B., Günay, G., \& Çeştepe, H. (2014). Consumers Perceived Online Purchasing. Academic Journal of Interdisciplinary Studies, 3(3), 185.

Lavieri, P. S., Dai, Q., \& Bhat, C. R. (2018). Using virtual accessibility and physical accessibility as joint predictors of activity-travel behavior. Transportation Research Part A: Policy and Practice, 118, 527-544.

Lavieri, P. S., Garikapati, V. M., Bhat, C. R., Pendyala, R. M., Astroza, S., \& Dias, F. F. (2017). Modeling individual preferences for ownership and sharing of autonomous vehicle technologies. Transportation research record, 2665(1), 1-10. 
Lean, O. K., Zailani, S., Ramayah, T., \& Fernando, Y. (2009). Factors influencing intention to use e-government services among citizens in Malaysia. International Journal of Information Management, 29(6), 458-475.

Mashuri, A., \& Zaduqisti, E. (2019). Explaining Muslims' Aggressive Tendencies Towards the West: The Role of Negative Stereotypes, Anger, Perceived Conflict and Islamic Fundamentalism. Psychology and Developing Societies, 31(1), 56-87.

Morcos, M., Stavropoulos, V., Rennie, J. J., Clark, M., \& Pontes, H. M. (2019). Internet gaming disorder: compensating as a Draenei in World of Warcraft. International Journal of Mental Health and Addiction, 1-17.

Nunayon, S. S., Olanipekun, E. A., \& Famakin, I. O. (2020). Determining key drivers of efficient electricity management practices in public universities in Southwestern Nigeria. International Journal of Sustainability in Higher Education.

Overby, J. W., \& Lee, E. J. (2006). The effects of utilitarian and hedonic online shopping value on consumer preference and intentions. Journal of Business Research, 59(10-11), 1160-1166.

Parasuraman, A. (2000). Technology Readiness Index (TRI) a multiple-item scale to measure readiness to embrace new technologies. Journal of Service Research, 2(4), 307-320.

PewResearch. (2015). Muslims. Pewforum.org. Retrieved on 14 May 2020 from https://www.pewforum.org/2015/04/02/muslims/

Qi, S., Law, R., \& Buhalis, D. (2017). Comparative evaluation study of the websites of Chinabased and international luxury hotels. Journal of China Tourism Research, 13(1), 1-25.

Revadi, A. M., Apoorva, D. A., Mehta, A. N., \& LK, S. S. (2018). Using Sentiment Analysis for Website Evaluation. International Journal of Advanced Research in Computer Science, 9(Special Issue 3), 33

Rezaei, S., Amin, M., \& Ismail, W. K. W. (2014). Online repatronage intention: an empirical study among Malaysian experienced online shoppers. International Journal of Retail and Distribution Management, 42(5), 390-421.

Sandıç̧ı, Ö. (2011). Researching Islamic marketing: past and future perspectives. Journal of Islamic Marketing, 2(3), 246-258.

Schreiber, J. B. (2017). Update to core reporting practices in structural equation modeling. Research in Social and Administrative Pharmacy, 13(3), 634-643.

Setiawati, L. M., Chairy, C., \& Syahrivar, J. (2019). Factors Affecting the Intention to Buy Halal Food by the Millennial Generation: The Mediating Role of Attitude. DeReMa (Development Research of Management): Jurnal Manajemen, 14(2), 175-188.

Setyastuti, Y., Suminar, J. R., Hadisiwi, P., \& Zubair, F. (2019). Millennial Moms: Social Media as The Preferred Source of Information about Parenting in Indonesia. Library Philosophy and Practice, 1-15.

Sieber, S., \& Sabatier, J. V. (2003, June). Uses and attitudes of young people toward technology and mobile telephony. In 16th BLED International Conference on Electronic Commerce: eTransformation, Bled, Slovenia.

Syahrivar, J., \& Azizah, P. A. (2018). The role of religiosity and brand perception in the brand preference for halal cosmetics: a case study of family-owned Islamic cosmetic business. International Journal of Technology Transfer and Commercialisation, 16(2), 146-158.

Syahrivar, J., \& Pratiwi, R. S. (2018). A Correlational Study of Religiosity, Guilt, and Compensatory Consumption in the Purchase of Halal Products and Services in Indonesia. Advanced Science Letters, 24(10), 7147-7151.

Tan, G. W., \& Wei, K. K. (2006). An empirical study of Web browsing behaviour: Towards an effective Website design. Electronic Commerce Research and Applications, 5(4), 261-271.

Wilson, J. A., \& Liu, J. (2011). The challenges of Islamic branding: navigating emotions and halal. Journal of Islamic Marketing, 2(1), 28-42. 
Yuana, S. L., Sengers, F., Boon, W., \& Raven, R. (2019). Framing the sharing economy: A media analysis of ridesharing platforms in Indonesia and the Philippines. Journal of Cleaner Production, 212, 1154-1165.

Zainudin, M. I., Hasan, F. H., \& Othman, A. K. (2019). Halal brand personality and brand loyalty among millennial modest fashion consumers in Malaysia. Journal of Islamic Marketing.

Zhong, L., Leung, D., Law, R., Wu, B., \& Shao, J. (2014). An application of the capability maturity model for evaluating attraction websites in mainland China. International Journal of Tourism Research, 16(5), 429-440. 